\title{
O Apostolado Positivista do Brasil e o SPILTN: propostas e políticas para a questão indígena no Brasil
}

\author{
Cintia Régia Rodrigues ${ }^{1 ; *}$ \\ ${ }^{1}$ Universidade Regional de Blumenau, Blumenau, Santa Catarina, Brasil
}

\section{RESUMO}

O presente artigo tem como objetivo analisar as interpretaçóes acerca do Positivismo no Brasil nos primórdios do século XX, principalmente no que tange às populaçôes nativas. A respeito dessas interpretaçôes, o Comtismo postulava a "lei dos três estados", segundo a qual a humanidade passara pelas etapas: teológica (que se dividia em três idades sucessivas: a fetichista, a politeísta e a monoteísta), a metafísica e a positiva. Os positivistas no Brasil ressaltavam, com base nas ideias de Auguste Comte, que as populaçôes nativas eram fetichistas e estariam no primeiro estágio mental da humanidade. Entáo, seria necessário ampará-las e protegê-las a fim de que pudessem atingir o estágio mental da civilização. Para alcançar o objetivo mencionado, pretende-se averiguar as propostas elaboradas pelo Apostolado Positivista do Brasil para a questão indígena no contexto de criação do Serviço de Proteção aos Índios e Localização de Trabalhadores Nacionais (SPILTN) a partir de um conjunto de textos impressos. O SPILTN foi uma nova política federal criada em 1910 pelo Estado, que tratava da questáo indígena.

Palavras-chave: Populaçôes indígenas; Positivismo; APB; SPILTN; Estado.

\section{The Positivist Apostolate of Brazil and SPILTN: proposals and policies for indigenous issues in Brazil}

\section{ABSTRACT}

This article aims to analyze the interpretations of positivism in Brazil in the early twentieth century, particularly when it referred to native populations. Regarding these interpretations, Comtism postulated the "law of three stages", according to which humanity passed through the following stages: theological, (which was divided into three consecutive ages: fetishism, polytheism, and monotheism); metaphysics and positive. Positivists in Brazil claimed that

DOI: http://dx.doi.org/10.1590/2237-101X02004009

Artigo recebido em 22 de maio de 2017 e aceito para publicaçáo em 9 de abril de 2018.

* Professora da Universidade Regional de Blumenau/Departamento de História e Geografia, Blumenau/SC

— Brasil. E-mail: regia_rs@hotmail.com. https://orcid.org/0000-0003-3319-3702. 
native populations were fetishists, and would be the first human mental stage from Auguste Comte's ideas. Therefore, it was necessary to care for them and protect them so that they could reach the mental state of civilization. That being said, the article examines the proposals made by the Positivist Apostolate of Brazil for the Indigenous issue at the time of the Indian Protection Service and National Workers Location (SPILTN)'s creation by analyzing a set of published texts. The SPILTN was a new federal policy created in 1910 by the National State in charge of the Indigenous question.

Keywords: Indigenous peoples; Positivism; APB; SPILTN; National state

\section{El Apostolado Positivista de Brasil y el SPILTN: propuestas y políticas para la cuestión indígena en Brasil}

\section{RESUMEN}

El presente artículo tiene como objetivo analizar las interpretaciones acerca del Positivismo en Brasil para comienzos del siglo XX, principalmente en lo que se refiere a las poblaciones nativas. Con respecto a esas interpretaciones, el Comtismo postulaba la "ley de los tres estados", según la cual la humanidad pasará por las etapas: teológica (que se dividía en tres edades sucesivas: la fetichista, la politeísta y la monoteísta), la metafísica y la positiva. Los positivistas en Brasil, resaltaban con base en las ideas de Augusto Comte, que las poblaciones nativas eran fetichistas y estarían en el primer estado mental de la civilización. Para alcanzar el objetivo mencionado, se pretende averiguar las propuestas elaboradas por el Apostolado Positivista de Brasil para la cuestión indígena en el contexto de la creación del Servicio de Protección a los Indios y Localización de Trabajadores Nacionales (SPILTN) a partir de un conjunto de textos impresos. El SPILTN fue una nueva política federal creada en 1910 por el Estado Nacional que trataba de la situación indígena.

Palabras clave: Poblaciones Indígenas; Positivismo; APB; SPILTN; Estado Nacional.

A política brasileira, principalmente nos primórdios da república, esteve alicerçada em novas teorias filosóficas advindas da Europa, como o darwinismo, o spencerismo e os determinismos científicos, além de ter influência, principalmente, das interpretaçóes realizadas acerca do Positivismo que faziam parte do "conjunto de procedimentos" capaz de mobilizar e orientar a adoção de novos padróes político-institucionais, econômicos, sociais e culturais. O Positivismo esteve presente em vários campos no Brasil, figurando nos principais setores influentes: nos governos federal e estadual, no legislativo, nos cursos superiores, no setor militar, na cultura. 
O objetivo primordial do artigo é analisar de que modo as populaçóes indígenas eram apresentadas pelos representantes do apostolado positivista do Brasil, destacando como esses grupos nativos deveriam atingir a "civilização", a partir das interpretaçóes acerca do Positivismo no país, principalmente no contexto da efetiva criação do SPILTN. Pretende-se, nesse sentido, contribuir para a historiografia que trata da constituição da política indigenista nos primórdios da república no Brasil, percebendo o papel desempenhado pela Igreja positivista e pelos escritos de alguns confrades, em especial Miguel Lemos e Raimundo Teixeira Mendes, no processo de constituiçáo das diretrizes oficiais do órgão federal em questão. Desse modo, como eixo central pretende-se demonstrar a importância do Apostolado Positivista do Brasil, principalmente nas questóes indígenas.

As referências bibliográficas adotadas no presente texto tematizam as interpretaçóes acerca do Positivismo no Brasil e as ideias do Apostolado positivista sobre os indígenas, a partir dos estudos da obra de Auguste Comte (1934) e da historiografia recente. Busca-se apreciar a política indigenista na República (SPILTN) e suas articulações com os projetos positivistas, desenvolvendo, ao longo do trabalho, debates sobre os objetivos propostos a partir da historiografia citada. São também estudados os documentos publicados pela Igreja positivista.

Os textos positivistas que se articulam com a criação do SPILTN e que foram selecionados para o presente trabalho são os seguintes: A civilização dos indígenas brasileiros e a politica moderna (1910), Em defesa dos selvagens brasileiros (1910), e, ainda, A influência positivista no atual Serviço de Proteção aos Índios e Localização dos Trabalhadores Nacionais (1911), escritos por Raimundo Teixeira Mendes. De Miguel Lemos, estudamos José Bonifácio. A propósito do novo serviço de proteção aos indios (1910).

É pertinente enfatizar que o Positivismo cresceu de forma bastante heterogênea no Brasil, sendo que a disseminação das ideias não pode ser definida como uma simples importação de modelos advindos da Europa. Na historiografia, é comum encontrar obras que buscam identificar os adeptos da doutrina utilizando a distinção clássica entre positivistas ortodoxos e heterodoxos, como as de Alonso ${ }^{1}$ e Carvalho. ${ }^{2}$ Para Angela Alonso, ${ }^{3}$ os positivistas ortodoxos eram os que aceitavam a obra de Auguste Comte na sua totalidade, tanto na perspectiva filosófica quanto na religiosa. Dentre estes, muitos eram filiados à Igreja Positivista do Brasil. Já os positivistas heterodoxos, a autora ressalta, não eram um grupo unificado; existiam adeptos de diferentes localidades e inclinações, e que produziam distintas interpretaçóes da teoria positivista de acordo com realidades particulares. No entanto, a classificação dos positivistas nessas duas linhas não leva em consideração as especificidades da difusão das ideias positivistas no Brasil, que ocorreu de maneira bastante fragmentada e por meio de múltiplas apropriações e ressignificações.

\footnotetext{
${ }^{1}$ ALONSO, Angela. Ideias em movimento: a geração 1870 na crise do Brasil-Império. São Paulo: Paz e Terra, 2002.

${ }^{2}$ CARVALHO, José Murilo. A formação das almas: o imaginário da República do Brasil. São Paulo: Companhia das Letras, 1990.

${ }^{3}$ ALONSO, Angela. Ideias em movimento: a geração 1870 na crise do Brasil-Império, op. cit.
} 
De acordo com José Murilo de Carvalho, ${ }^{4}$ a filosofia positivista considerava necessária a implantação do regime republicano no Brasil como o último passo para a constituição da sociedade positiva. Assim, a própria república representava o progresso. Os positivistas ortodoxos $s^{5}$ ainda salientavam que a ditadura republicana era parte integrante do processo de transição ao estado positivo. Carvalho destaca, a partir de Raimundo Teixeira Mendes, o modo pelo qual ocorreria a evolução da humanidade. Teixeira Mendes havia sido vice-diretor da Igreja Positivista do Brasil, de 1903 até 1927, e definiu a significação do lema "Ordem e Progresso":

De um mundo até entáo dividido entre as duas tendências, com excessos de ordem sendo substituídos por excessos de progresso, passava-se, em consequência das descobertas científicas da dinâmica social do Mestre, a uma concepção que unia os dois polos. Tal concepção era a base da nova dinâmica de confraternização universal, prenúncio da fase final de evolução da humanidade. ${ }^{6}$

Com a proclamação da república, ressurge a questão da nacionalidade. Esta esteve adormecida desde a independência do Brasil em 1822, quando os holofotes ideológicos voltaram-se para a construção de uma nação moderna, independente, voltada para os ideais da Revolução Francesa, como a necessária equivalência entre povo e nação. Nesse sentido, também a preocupação prática esteve alicerçada na conquista do território e no próprio avanço da sociedade nacional, buscando-se construir um Estado homogêneo que não se fracionasse, ao contrário daquilo que estava acontecendo nos Estados oriundos do império colonial espanhol. ${ }^{7}$

A partir do processo de construção da república no Brasil, a questão indígena voltou a ficar em evidência. Em função da instauração do regime republicano, a discussão em torno da "identidade nacional" e do "projeto nacional" ganhou um novo impulso. Como a nacionalidade voltava a ser tema de discussão, a retomada da questão indígena era favorecida.

No final do século XIX e nos primórdios do século XX, no Brasil, um grupo de pensadores positivistas ergueu a bandeira em favor da causa indígena. Cabe lembrar que, com a instauração da república, os positivistas detinham uma certa influência entre os militares, por muitos serem adeptos das ideias de Comte. Desse modo, por meio do Apostolado Positivista do Brasil surgiu a única proposta encaminhada à Assembleia Nacional Constituinte, em 1891, sobre os direitos dos índios:

\footnotetext{
${ }^{4}$ CARVALHO, José Murilo. A formação das almas: o imaginário da República do Brasil, op. cit.

5 "Positivistas ortodoxos", nesse contexto, era a denominação dada aos membros do Apostolado Positivista do Brasil.

${ }^{6}$ Ibidem, p. 113.

${ }^{7}$ Carvalho destaca em sua obra as opções políticas escolhidas para o Brasil e América Espanhola. Ver: CARVALHO, José Murilo de. Construção da ordem: a elite política imperial e Teatro de Sombras: a política imperial. Rio de Janeiro: UFRJ, 1996.
} 
Art. 1o - A República dos Estados Unidos do Brasil é constituída pela livre federação dos povos circunscritos dentro dos limites do extinto Império do Brasil. Compóe-se de duas sortes de estados confederados, cujas autonomias são igualmente reconhecidas e respeitadas segundo as fórmulas convenientes a cada caso, a saber:

1. Os Estados Ocidentais Brasileiros sistematicamente confederados e que provêm da fusão do elemento europeu com o elemento africano e o americano aborígene.

11. Os Estados Americanos Brasileiros empiricamente confederados, constituídos pelas hordas fetichistas esparsas pelo território de toda a República. A federação deles limita-se à manutenção das relaçóes amistosas hoje reconhecidas como um dever entre naçóes distintas e simpáticas, por um lado; e, por outro lado, em garantir-lhes a proteção do Governo Federal contra qualquer violência, quer em suas pessoas, quer em seus territórios. Estes não poderão jamais ser atravessados sem o seu prévio consentimento pacificamente solicitado e só pacificamente obtido. (Miguel Lemos e R. Teixeira Mendes, Bases de uma Constituição política ditatorial federativa para a República Brasileira, 1890) ${ }^{8}$

A proposta continha o reconhecimento da soberania indígena e atentava para a constituição étnica do Brasil, citando a fusão entre os elementos europeu, africano e indígena. Os positivistas acreditavam que as naçóes indígenas eram livres, como quaisquer outras, e consideravam que os índios eram donos dos territórios que ocupavam, pois "nenhum homem de coração pode contestar que os selvagens são os senhores das terras que habitam, com títulos tão válidos como os que qualquer nação ocidental pode invocar, para justificar a posse do território que ocupa"?

É pertinente destacar o contexto no qual a proposta do Apostolado Positivista é apresentada. A recém-fundada república, organizada em uma federação, delegava aos estados uma maior autonomia, não estando, porém, totalmente alheia às questões indígenas, mesmo que a maioria dos problemas em relação a eles ainda fosse mais discutida em níveis estaduais. Compete ressaltar que todos os ministérios federais estiveram envolvidos, de alguma maneira, com os assuntos referentes aos silvícolas, devido aos desentendimentos em torno dos problemas fundiários, ligados diretamente à questão indígena. Eram constantes os confrontos entre os colonos e os indígenas, uma vez que, com o término da escravidão no Brasil, os imigrantes eram os trabalhadores em potencial, sendo que muitos destes adquiriram terras junto ao governo federal, passando por cima dos índios. Afinal, estes não eram entendidos como trabalhadores, pois, devido ao seu modo de

\footnotetext{
${ }^{8}$ Artigos publicados em janeiro de 1910 e maio de 1910, respectivamente, por MENDES, Raimundo Teixeira. A civilizaçâo dos indígenas brasileiros e a política moderna. Rio de Janeiro: Igreja e Apostolado Positivista do Brasil, n. 294, 1910, p. 6; e Em defesa dos selvagens brasileiros. Rio de Janeiro: Igreja e Apostolado Positivista do Brasil, n. 300, 1910, p. 16.

${ }^{9}$ MENDES, Raimundo Teixeira. Em defesa dos selvagens brasileiros, op. cit., p. 11.
} 
vida, não estariam preparados para se juntar às fileiras da expansão da sociedade nacional, pelo menos até a efetiva instalação do SPILTN.

Nesse período, representantes do Apostolado Positivista elaboraram inúmeros artigos sobre o tema. Dentre eles, destaca-se o trabalho de Miguel Lemos, que foi presidente da Igreja Positivista do Brasil (IPB) ${ }^{10}$ no período de 11 de maio de 1881 até o seu afastamento, em 1903, quando assume, na qualidade de vice-diretor da IPB, Teixeira Mendes.

A IPB procurou manter vivas as ideias de José Bonifácio, ${ }^{11}$ até então desapreciadas entre as classes dominantes e ignoradas pela massa popular. Miguel Lemos, em setembro de 1910, destaca a importância de se haver tirado do total esquecimento o trabalho de José Bonifácio, que afinal elaborara um plano completo para a organização de uma nova nacionalidade, sem a exclusão dos elementos constitutivos da população brasileira. ${ }^{12}$ Teixeira Mendes, em sua obra A influência Positivista no atual Serviço de Proteção aos Índios e Localização dos Trabalhadores Nacionais $^{13}$ ressalta a posição de vanguarda da IPB, por trazer à tona os dois projetos de José Bonifácio acerca da abolição da escravatura e da civilização dos selvagens. Também trata de reforçar que só através do Positivismo havia sido dada a solidez teórica necessária para realizar o desejo de proteção aos selvagens e também aos africanos:

Porque o Positivismo é a única doutrina que conduz, em virtude de seu relativismo altruísta e científico, independente de qualquer consideração sobrenatural, a respeitar a civilização fetíchica, em que se acham os selvagens, e, no fundo, os descendentes dos africanos, de modo a aguardar que eles evoluam — já espontaneamente, já mediante os pacíficos contatos com os ocidentais - até o nível em que estes se acham presentemente, e possam atingir no futuro (...). Fora do Positivismo, essa concepção não existia, e nem podia existir, da mesma sorte, por exemplo, que a mecânica celeste não existia antes de Newton. ${ }^{14}$

Conforme Ribeiro, os positivistas:

\footnotetext{
${ }^{10}$ A IPB também é denominada Apostolado Positivista do Brasil.

${ }^{11}$ José Bonifácio apresentou suas ideias sobre a "civilização dos índios bravos" primeiramente às Cortes de Lisboa em 1821. Após a independência do Brasil, ele reapresenta sua proposta para a Assembleia Constituinte do Império em 1823, os Apontamentos para a civilização dos Índios Bravos do Império do Brasil. Nesse programa ressaltava que a assimilação da população indígena "brava" deveria se dar por métodos "brandos". O documento é dividido em duas partes, a primeira destaca que os nativos se encontravam no estado de selvageria e por estarem nesta condiçấo primitiva poder-se-ia chegar à civilização. Na segunda parte do documento, Bonifácio destaca a partir dos 44 itens as principais formas que a "razão" e a "experiência" aconselhavam para melhor obter a civilização dos indígenas. CALDEIRA, Jorge. José Bonifácio de Andrada e Silva. São Paulo: Editora 34, 2002. ${ }^{12}$ LEMOS, Miguel. José Bonifácio. A propósito do novo serviço de proteção aos índios. Rio de Janeiro: Igreja e Apostolado Positivista do Brasil, Tip. do IPB, n. 305, setembro, 1910.

${ }^{13}$ MENDES, Raimundo Teixeira. A influência positivista no atual Serviço de Proteção aos Índios e Localização dos Trabalhadores Nacionais. Rio de Janeiro: Igreja e Apostolado Positivista do Brasil, Tip. do IPB, n. 334, jun. 1911. ${ }^{14}$ Ibidem, p. 7.
} 
baseados no evolucionismo humanista de Augusto Comte, propugnavam pela autonomia das naçóes indígenas na certeza de que, uma vez libertas de pressóes externas e amparadas pelo Governo, evoluiriam espontaneamente. Segundo o modo de ver dos positivistas, os índios, mesmo permanecendo na etapa "fetichista" do desenvolvimento do espírito humano, eram susceptíveis de progredir industrialmente. ${ }^{15}$

O Comtismo postulava a "lei dos três estados", ${ }^{16}$ segundo a qual a humanidade passara pelas etapas: teológica (que se dividia em três idades sucessivas: a fetichista, a politeísta e a monoteísta), a metafísica e a positiva. Sobre a lei dos três estados, Sponchiado afirma:

No Estado teológico — estado natural e primitivo da inteligência humana —, os fenômenos explicam-se pela intervenção arbitrária de agentes sobrenaturais que ficam responsáveis por todas as transformaçóes do universo. No Estado metafísico, forças abstratas tomam lugar dos agentes sobrenaturais na explicação da experiência humana. No Estado positivo, a inteligência do homem, reconhecendo a impossibilidade de obter noçóes absolutas, renuncia à procura da origem e do destino do universo e ao conhecimento das causas íntimas dos fenômenos para preocupar-se exclusivamente com o descobrimento, pelo uso combinado do raciocínio e da observação, das leis efetivas, isto é, das relações invariáveis de sucessão e semelhança que ligam os fenômenos. ${ }^{17}$

Como os positivistas ressaltavam que as populações nativas eram fetichistas e estariam no primeiro estágio mental da humanidade, seria necessário ampará-las e protegê-las, a fim de que pudessem atingir o estágio mental da civilização. Então, seria necessário elaborar um projeto para que essa prática desses frutos.

Constantemente, o Apostolado criticava a forma violenta como várias populaçóes nativas eram dizimadas no Brasil. Também ressaltava que apenas através dos preceitos comteanos o nativo poderia evoluir para ingressar nas fileiras do progresso. De acordo com Gagliardi, Teixeira Mendes procurava:

(...) ressaltar que a impunidade daqueles que assassinavam os indígenas e ocupavam seus territórios era decorrente de uma consciência que se formara no sertanejo, no governo e nas camadas dominantes, de que as terras lhe pertenciam por serem eles os agentes do progresso. (...) Considerava injustificável usar a violência com o pretexto de civilizar, uma vez que o indígena fazia parte de uma grande

\footnotetext{
${ }^{15}$ RIBEIRO, Darci. Os indios e a civilização: a integração das populaçôes indígenas no Brasil moderno. Petrópolis: Vozes, 1986, p. 134.

${ }^{16}$ Ver obras de Comte, principalmente: COMTE, Auguste. Catecismo Positivista: ou sumária exposição da Religião da Humanidade. Trad. de Miguel Lemos. Rio de Janeiro: Igreja e Apostolado Positivista do Brasil, 1934. ${ }^{17}$ SPONCHIADO, Breno Antônio. O Positivismo e a colonização do Norte do Rio Grande do Sul. Frederico Westphalen: URI, 2005, p. 126.
} 
diversidade de povos, com valores e hábitos peculiares. (...) insistia em que apenas o altruísmo, celebrado pela poesia e esclarecido pela ciência, seria capaz de redimir os povos indígenas. Segundo Teixeira, “(...) no momento presente a humanitária e patriótica atitude do cidadão Rodolfo Miranda, Ministro da Agricultura, nos promete que a proteção fraternal (não a catequese, que é impossivel) dos selvagens brasileiros vai começar a tornar-se efetiva por parte do governo". ${ }^{18}$

Teixeira Mendes reforça a importância do Positivismo, enfatizando a ideia de que, a partir da lei de três estágios (teológico, metafísico e positivo), a doutrina alicerçaria as condiçóes para a integração natural do indígena à sociedade nacional. Tal se daria por sua própria vontade, ainda que este se encontrasse no estágio teológico, mais precisamente na idade fetichista. Portanto, seria possível aos nativos evoluir espontaneamente ao estágio positivo. Note-se que os estudos realizados por Comte acerca do fetichismo foram empreendidos a partir da referência às populaçóes africanas, mas é possível estabelecer uma relação com as populaçóes indígenas, visto que ambas se caracterizariam pelo nomadismo e pela percepção fetichista dos fenômenos que presenciavam.

O teórico Auguste Comte, em sua obra publicada em 1852, ${ }^{19}$ contempla as vantagens do fetichismo em relação ao politeísmo e ao monoteísmo, argumentando que o fetichismo se assemelharia mais ao Positivismo, pois aproximaria o homem da natureza, ao invés de afastá-lo. Ele também sugere "a queima de etapas”, fazendo com que ocorresse a transição direta do fetichismo para o Positivismo. A prática poderia acelerar o desenvolvimento dos povos africanos sem que ocorressem traumas. Entretanto, dentro do pensamento comteano, para os indivíduos esse processo poderia ser catastrófico. Nas palavras de Comte:

(...) A possibilidade de semelhante sucesso resulta da profunda afinidade do positivismo com o fetichismo, que não difere daquele, quanto ao dogma, senão em confundir a atividade da vida, e, quanto ao culto, em adorar os materiais em vez de produtos. Em toda iniciação humana, espontânea ou dirigida, o fetichismo constitui o único modo do regime fictício verdadeiramente inevitável, porque ele surge em uma época em que a espécie e o indivíduo são incapazes de reflexôes quaisquer. (...) Se tivéssemos empenho em preservar nossos filhos do politeísmo, poderíamos consegui-lo prolongando o estado fetíchico até que, por modificações graduais, ele fosse terminar no positivismo. Mas este esforço careceria então de oportunidade, sem falar de sua tendência a perturbar o surto natural da imaginação humana. O caso é muito diverso tratando-se da evolução coletiva da África central, onde tais transformações comportam a mais salutar eficácia, tanto local, como universal. ${ }^{20}$

\footnotetext{
${ }^{18}$ GAGLIARDI, José Mauro. O indígena e a república. São Paulo: Hucitec, 1989, p. 193. Grifo do autor.

${ }^{19}$ COMTE, Auguste. Catecismo Positivista: ou sumária exposiçăo da religião da humanidade. Trad. de Miguel Lemos. Rio de Janeiro: Igreja e Apostolado Positivista do Brasil, [1852] 1934.

${ }^{20}$ Ibidem, p. 385-386.
} 


\section{Propostas e políticas para os índios}

Teixeira Mendes, em 1910, quando foi avisado da iminência da criação de um órgão responsável pela assistência aos nativos (SPILTN), elabora, em nome do Apostolado Positivista, um programa que descreve os princípios que deveriam reger o citado órgão. São eles:

Respeitar os territórios e as instituiçôes das tribos selvagens tratando-as como naçôes independentes como realmente são, perante a moral e a razão. Demarcar, pois, com escrupulosa lealdade esses territórios e punir qualquer violaçáo por parte dos chamados civilizados.

Promover pacificamente a abolição da antropofagia, das guerras e inimizades entre diversas tribos;

Desenvolver entre os indígenas o asseio, o vestuário, a cultura musical;

Facilitar a instituição da vida sedentária, aperfeiçoando as habitações, desenvolvendo os hábitos e processos industriais, sobretudo agrícolas.

Respeitar todas as livres tentativas de transformação da cultura moral e mental, mediante os esforços espontâneos das fiéis de qualquer religião ou dos adeptos de qualquer doutrina. Cumpre, para isso, que os missionários quaisquer fiquem exclusivamente entregues ao seu prestígio próprio, não podendo, em caso algum, solicitar a intervenção violenta do Governo, sob o pretexto de reprimir ou impedir atrocidades dos selvagens. ${ }^{21}$

Apesar de toda a campanha dos positivistas em prol dos indígenas, nenhuma de suas propostas foi consolidada na Constituiçáo Federal em 1891, na qual o índio nem foi citado. Na lei máxima do país, em seu artigo 64, tratava-se das terras devolutas, que poderiam ser repassadas para os estados federados, desde que ficassem reservadas ao governo federal as terras necessárias para a defesa das fronteiras brasileiras. Mas, durante algum tempo, ocorreu uma certa incerteza quanto à aplicaçấo correta desse artigo, uma vez que havia entendimento de que as terras indígenas na sua totalidade tinham passado para as mãos dos estados. $\mathrm{Na}$ verdade, o que passou aos estados foram as terras devolutas (artigo 64), entre as quais constavam, desde 1887 , as terras dos extintos aldeamentos. ${ }^{22}$

Manuela Carneiro da Cunha, porém, apresenta o argumento de que as terras dos aldeamentos indígenas extintos, ao contrário do artigo 64, não poderiam ser caracterizadas como devolutas:

\footnotetext{
${ }^{21}$ MENDES, Raimundo Teixeira. A civilização dos indígenas brasileiros e a política moderna, op. cit., p. 7.

${ }^{22}$ CUNHA, Manuela Carneiro da. Os direitos do indio: ensaios e documentos. São Paulo: Brasiliense, 1987.
} 
Aos Estados ficaram as terras devolutas; ora, as terras do “indigenato", sendo terras congenitamente possuídas, não são devolutas, isto é, são originariamente reservadas, na forma do Alvará de 1 de abril de 1680 e por dedução da própria lei de 1850; as terras reservadas para o "colonato de indígenas" passaram a ser sujeitas às mesmas regras que as "concedidas para o colonato de imigrantes", salvo as cautelas de orfanato em que se acham os índios (...). ${ }^{23}$

Devido a essa confusão de ordem jurídica, muitos aldeamentos foram desintegrados e essas terras passaram a ser denominadas devolutas, repassadas aos governos estaduais que, em seguida, vendiam-nas ou utilizavam-nas para assentamento de colonos.

O programa elaborado por Teixeira Mendes previa a demarcação de terras para os nativos, sendo que deveria ser punida qualquer violação por parte dos ditos "civilizados". Por outro lado, sugeria que as populaçóes nativas deveriam modificar seus hábitos culturais, assumindo "o asseio, o vestuário, a cultura musical". Isso nos remete aos ajustes realizados na teoria positivista quando da interpretação das ideias advindas da Europa no final do século XIX e primórdios do século XX, visto que, de acordo com o Positivismo, o nativo deveria evoluir "espontaneamente" ao estágio positivo. Mas, como é observado, o confrade do Apostolado ressaltava o uso de métodos que pretendiam trazer o nativo à sociedade nacional, ao processo de modernização, que deveria perpassar todos os setores da sociedade brasileira. Nota-se que a ideia do Positivismo no Brasil, transmitida pelo Apostolado - neste caso, a partir de Teixeira Mendes - era um tanto dúbia, pois se, por um lado, o seguidor de Comte pretendia assegurar o respeito para com as populaçóes nativas, por outro sugeria mudanças a serem empreendidas na dinâmica cultural das populaçóes autóctones. Outro elemento interessante da proposta acena para a possibilidade de missionários, por exemplo, da Igreja Católica, poderem continuar a realizar seus trabalhos de evangelização junto aos nativos, desde que náo obtivessem "apoio governamental", sob um pretexto de impedir atos selvagens por parte dos indígenas.

Dentro dessa perspectiva de contradição do próprio ideal positivista, em outro escrito de Teixeira Mendes observa-se a sugestão de "Incorporação do Proletariado na Sociedade Moderna”, distanciando-se das propostas da IPB de proteção dos territórios nativos, de reconhecimento da autonomia e soberania das populaçóes nativas. $\mathrm{O}$ nativo aqui deveria ser incorporado à sociedade nacional, uma vez que:

(...) não há possibilidade de haver um desenvolvimento e aperfeiçoamento do homem e, mais do que isso, não é possível "elevar o caráter brasileiro" sem que se eleve o proletariado, que é quase toda a nação. Não há como esperar a regeneração da Pátria sem que as Famílias Proletárias estejam em condições de "produzir verdadeiros homens". ${ }^{24}$

\footnotetext{
${ }^{23}$ Ibidem, p. 74.

${ }^{24}$ LEITE, Jurandyr C. F. Proteção e incorporação: a questão Indígena no pensamento político do Positivismo ortodoxo. Revista de Antropologia, v. 30/31/32, p. 255-275, 1989, p. 259. Grifo nosso.
} 
As propostas de Teixeira Mendes começam a se materializar com o convite do Ministro da Agricultura, Rodolpho Miranda, para que o marechal Cândido Rondon assumisse a direção do que posteriormente se designaria SPILTN. Cândido Manoel da Silva Rondon professava sua fé na ciência:

Porque o dogma do Positivismo é a própria ciência e, como esta, universal, relativo, demonstrável (...). Porque é, ao mesmo tempo, a religiáo do amor, a religiáo da ordem, a religião do progresso (...). Creio que a ciência, a arte e a indústria hão de transformar a terra em paraíso, para todos os humanos, sem distinção de raças, crenças e naçóes (...); Creio nas leis da sociologia, fundada por Auguste Comte, e, por isso, na incorporaçáo do proletariado e das naçóes consideradas sem civilização à sociedade moderna (...); Creio que a missão dos intelectuais é, sobretudo, o preparo das massas humanas desfavorecidas. ${ }^{25}$

Com a criaçáo do Serviço de Proteção aos Índios e Localizaçáo de Trabalhadores Nacionais (SPILTN) em 1910, o marechal Cândido Rondon assume o cargo de presidente do órgão, em função de seus trabalhos na Comissão das Linhas Telegráficas de Mato Grosso ao Amazonas entre os anos de 1906 a 1909, quando esteve em contato com indígenas de várias tribos. A prática da nova política indígena foi alicerçada na experiência pessoal de Rondon, nos 20 anos de atividades entre os sertôes de Mato Grosso ao Amazonas. Quando o marechal foi convidado para assumir a chefia do órgáo federal de assistência aos índios, condicionou sua participação à aprovação dos ideais positivistas pelo governo federal no que dizia respeito ao SPILTN. Rondon era seguidor dos preceitos de Auguste Comte.

Em março de 1910, Rondon, em carta endereçada ao ministro Rodolfo Miranda, explicita as bases da política indigenista a ser implantada. Na carta transcrita a seguir, Rondon reforça a ideia de que os nativos deveriam evoluir naturalmente ao estágio positivo, sendo que a forma encontrada para se chegar a esse fim seria estabelecer laços fraternais entre a instituição a ser criada e as naçôes nativas:

Catequização dos indígenas, compreendendo a sua incorporação a nossa sociedade pela assimilaçáo de nossa indústria, nossas artes, bem como pela adoção de nossos hábitos — que resultam de nossas crenças religiosas, no sentido destes termos — julgo-a ser um problema diretamente inabordável no presente, em que por tantas crenças se repartem as preferências das populaçóes.

Como positivista e membro da Igreja Positivista do Brasil, estou convencido de que os nossos indígenas deveräo incorporar-se ao ocidente, sem que se tente forçá-lo pelo teologismo.

(...) usando sempre de processos fraternais, por-se-á mesmo mudar a residência de algumas tribos, quando isso convier aos interesses do país. ${ }^{26}$

\footnotetext{
${ }^{25}$ VIVEIROS, Esther de. Rondon conta sua vida. Rio de Janeiro: Livraria São José, 1958, p. 589-590. Grifo nosso.

${ }^{26}$ Ibidem, p. 346-347. Grifo nosso.
} 
Segundo Oliveira Filho, para melhor compreensão da proposta de Rondon de "proteção fraternal ao silvícola" é necessário compará-la com outras políticas governamentais, que se contrapunham ao processo de expansão do Estado Nacional, distinguindo-se radicalmente da "guerra justa", bem como de modalidades disfarçadas de extermínio dos indígenas por meio de açôes empreendidas por particulares. De acordo com o autor:

Os positivistas reelaboraram a polaridade entre "índio amigo" e "índio inimigo" (que, no fundo, é a dicotomia entre o índio "bom e o "mau", com o primeiro podendo-se concluir alianças, com o segundo justificando-se a guerra), situando todos os índios em uma só sequência evolutiva, sua adesão ou resistência sendo resultado da forma de intervençáo do homem branco. Com isso ilegitimava-se qualquer argumento que pretendesse justificar o extermínio. ${ }^{27}$

$\mathrm{O}$ autor ressalta que as populaçôes nativas, nos primórdios do século $\mathrm{XX}$, ainda estavam situadas na mesma categoria dos que, no passado, haviam sido alvo das "guerras justas". $\mathrm{Na}$ modernidade, esses não deveriam ser exterminados, mas sim transformados em uma populaçáo diretamente controlada pelo Estado por meio de uma prática tutelar, representada pela implantação do SPILTN.

Durante todo o processo de formação do Estado Brasileiro, promoveram-se políticas assimilatórias, entendidas como mecanismos voltados para proporcionar a "integração" das populaçôes nativas no Brasil à sociedade nacional. Em 1910, quando da criação do SPILTN, pretendeu-se novamente enquadrar o indígena na cultura europeia, agora sob uma nova ótica: o índio trabalhador nacional.

Segundo tal concepção, o Estado brasileiro estava apresentando às populações autóctones o progresso, de modo que eles iriam juntar-se às fileiras da modernização no Brasil, sob a égide do ideário positivista. Como destaca Lima:

A História "nacional" construída dentro dos critérios de "cientificidade" positivista situava os povos indígenas como origem e componentes da nação, pretendendo, mais que protegêelos (...) incorporá-los sob a tutela e hegemonia dos ocidentais. ${ }^{28}$

Os pensamentos que orientavam e sustentavam a nova legislação indigenista de 1910 alicerçavam-se na ideia de que a república brasileira deveria "resgatar as populações indígenas do extermínio a que estavam submetidas, desde os tempos coloniais, e colocá-las sob a sua

\footnotetext{
${ }^{27}$ OLIVEIRA FILHO, João Pacheco de. Ensaios em antropologia histórica. Rio de Janeiro: Ed. UFRJ, 1999, p. 144.

${ }^{28}$ LIMA, Antonio Carlos de Souza. Sobre indigenismo, autoritarismo e nacionalidade: consideraçóes sobre a constituição do discurso e da prática da Proteção Fraternal do Brasil. In: OLIVEIRA FILHO, João Pacheco de (Org.). Sociedades indígenas e indigenismo no Brasil. Rio de Janeiro: Marco Zero, 1987, p. 191. Grifo nosso.
} 
égide". ${ }^{29}$ Gagliardi ressalta que "o símbolo da nova orientação foi a substituição da palavra catequese pela palavra proteção" ${ }^{30}$ No entanto, assentar os nativos sob a política indigenista nacional também significava extermínio, não físico, mas cultural.

A partir de Hartog, podem ser feitas consideraçóes acerca da elaboração da política indigenista no país nos primórdios do século XX. O contato entre as culturas europeia e nativa estabelece uma situação em que se opõem o civilizado e o "outro". De acordo com o autor, "a questáo da alteridade levanta a da fronteira: onde passa a cesura entre o mesmo e o outro" ${ }^{31}$ Desse modo, as propostas da política oficial para os nativos foram dispostas a partir da "fronteira". ${ }^{32} \mathrm{O}$ Estado Nacional, imbuído de uma visão eurocêntrica, pretende trazer o "outro" para a civilização. Hartog, em sua obra, censura a forma como os gregos se relacionavam com o "outro", o elemento tido como bárbaro, mesmo que respeitassem suas culturas, sendo eles hindus, persas, egípcios e citas do século V a.C. O autor sugere:

Dizer o outro é enunciá-lo como diferente — é enunciar que há dois termos, a e b, e que a não é b. Por exemplo: existem gregos e não gregos. Mas a diferença não se torna interessante senão a partir do momento em que a e b entram num mesmo sistema. Não se tinha antes senáo uma pura e simples não coincidência. Daí para a frente, encontramos desvios, portanto uma diferença possível de ser assinalada e significativa entre os dois termos. Por exemplo: existem gregos e bárbaros. ${ }^{33}$

No entanto, sobre a questáo da "fronteira", Sahlins ${ }^{34}$ postula que se deve entender uma determinada sociedade como um todo, analisando os elementos que fazem parte do seu universo e aqueles integrados, advindos de outras culturas. Fazendo alusão à relação das culturas nativas com o governo federal, com base nas interpretações da cultura ocidental estabelecidas no Brasil desde o primeiro contato dos povos nativos com os europeus, ocorreram tentativas de subjugar o "outro". Afinal, considerava-se que a cultura europeia era a portadora da civilizaçáo, do desenvolvimento, da evoluçáo, sendo o "outro" em questáo o nativo, também era portador de cultura. Então, a fronteira deve aqui ser interpretada como uma linha tênue entre a civilização e a barbárie, o moderno e o primitivo, que se estabelecia, no entanto, entre duas sociedades contemporâneas.

Ainda trabalhando com as interpretaçôes do autor citado, em relação à cultura: "Não há história sem cultura. E vice-versa, na medida em que, no evento, a cultura não é o que era antes

\footnotetext{
${ }^{29}$ GAGLIARDI, José Mauro. O indígena e a república, op. cit., p. 226.

${ }^{30}$ Ibidem, p. 226. Grifo nosso.

${ }^{31}$ HARTOG, François. O espelho de Heródoto: ensaio sobre a representação do outro. Belo Horizonte: Editora UFMG, 1999, p. 97.

${ }^{32}$ BARTH, Fredrik. Los grupos étnicos y sus fronteiras: la organización social de las diferencias culturales. México: Fondo de Cultura Económica, 1976.

${ }^{33}$ HARTOG, François. O espelho de Heródoto: ensaio sobre a representação do outro, op. cit., p. 229.

${ }^{34}$ SAHLINS, Marshall. O "pessimismo sentimental" e a experiência etnográfica: Por que a cultura não é um “objeto” em via de extinção (Parte I). Mana, Rio de Janeiro, v. 3, n. 1, p. 41-73, abr. 1997.
} 
nem o que poderia ter sido." 35 Sahlins enfatiza que um acontecimento só se torna um evento, e, por conseguinte, história, quando definido pela ordem cultural na qual foi arraigado.

Dentro desse contexto, em que se estruturava uma nova orientação da conjuntura política em torno da questão dos nativos, não se dava apenas uma alteração de palavras. Tratava-se, na verdade, de uma nova política do Estado Nacional em relação aos indígenas, no contexto da modernização empreendida no Brasil nos primórdios do século XX. Nessa perspectiva, também é pertinente destacar que, quando da proclamação da república, ocorre um processo de laicização do trato junto às populaçóes autóctones, que durante o período colonial e imperial eram evangelizadas pela Igreja Católica. A nova prática estava em consonância com o término do regime do Padroado.

De acordo com o ministro da Agricultura Rodolpho Miranda, na exposição de motivos e Decreto no 8.072, de 20 de junho de 1910, que cria o SPILTN:

(...) Trata-se de sistematizar a proteção aos indios e prescrever regras à localização dos trabalhadores nacionais, questóes cuja importância decorre do próprio enunciado e que exigem dos poderes constituídos medidas conducentes a acautelar os altos interesses que elas representam, atenuando a influência duradoura de erros seculares, de prevenções tradicionais, que agravaram a infeliz condição dos nossos selvícolas, e promovendo o renascimento de extensas porções do território nacional, esterilizadas pelo abandono (...).

(...) se a piedade de religiosos os amparou e protegeu, não cabe à República, dentro do seu programa, negar-lhes cuidadosa assistência, fiel ao dever de estimular o desenvolvimento de suas faculdades morais, de sua capacidade de trabalho e de defender-lhes a vida.

(...) Não pode, porém, a República permanecer na imobilidade com que tem assistido, em muitos casos, ao massacre de índios e sua sujeição a um regime de trabalho semelhante ao cativeiro (...). Incumbelhe, ao contrário, velar por eles, guiá-los prudentemente, sem violência, porque, se são inferiores e fracos, mais iniludível é o dever de os defender contra os privilegiados e fortes.

E esse o objetivo do presente regulamento, em que a palavra catequese é substituida pela palavra proteçáo (...). (...) procurei reunir medidas que me pareceram mais adequadas a resolver o problema, sendo certo que muitas já têm a sanção da experiência de outros povos e o apoio dos mais notáveis juristas e pensadores brasileiros.

Nelas, tive empenho em consagrar os ensinos de um dos maiores amigos da raça indígena, condensados nesta fórmula: "Não aldear, nem pretender governar as tribos; deixá-las com seus costumes, sua alimentação, seu modo de vida; limitar-se a ensinar que não devem matar os de

\footnotetext{
${ }^{35}$ SAHLINS, Marshall. História e cultura: apologias a Tucídides. Rio de Janeiro: Zahar, 2006, p. 264.
} 
outras tribos", completando este pensamento com as providências precisas para evitar que os indios atentem igualmente contra a vida e a propriedade dos civilizados.

(...) $\mathrm{O}$ regulamento presente trata do segundo termo da questão: visa localizar aqueles dentre os nossos trabalhadores que, possuindo verdadeiras qualidades de homens de trabalho e de boa moral, queiram fixar-se nos "Centros Agrícolas", transformando-se, por força de sua capacidade produtora, em pequenos cultivadores, úteis a si mesmos e ao país.(...). ${ }^{36}$

Como se percebe, a proposta da política indigenista empreendida pelo Estado Nacional estava em consonância com as ideias do Apostolado Positivista do Brasil. Rocha destaca, em relação à estruturação do SPI:

(...) Para os criadores do Serviço de Proteção aos Índios, era dever do Estado, através da "proteção fraternal", dar condiçóes para os indios "evoluírem", de forma lenta, para um "estágio superior", que significaria a sua "incorporação" à nação brasileira. Indígena. (...) caberia ao SPI a garantia e defesa das terras indígenas. ${ }^{37}$

De acordo com Leite, a proteção aos nativos justificava-se por duas razóes complementares. ${ }^{38}$ Primeiramente, como forma de conter os crimes do passado e as violências contra os nativos, devido à ação egoísta de alguns homens. ${ }^{39}$ Em segundo lugar, a proteção era também justificada e requerida pela "impossibilidade atual de catequese", pois esta deveria conceber os nativos como naçóes independentes, respeitando seus territórios. ${ }^{40}$ Ainda conforme o autor, contida na ideia de proteção está a assimilação ou incorporação dos povos nativos à sociedade nacional. Também havia uma configuração pedagógica, voltada para mostrar aos nativos as benfeitorias da humanidade:

Em termos práticos significa sobretudo a proteção física na qual a demarcação de um território é imprescindível. Mas é, antes de tudo, uma proteção de "material humano", de "braços", que devem ser preenchidos de civilização, educados para o trabalho. A proteção fraternal tem em mente o "proletário" de uma nova fase pacífica-industrial, e objetiva isto na Pátria brasileira, com elementos que compóem nacionalidade como forma de manter a tradição e lutar contra a imigração. ${ }^{41}$

\footnotetext{
${ }^{36}$ MIRANDA, Rodolpho. Exposição de Motivos e Decreto no 8.072 de 20 de junho de 1910. Rio de Janeiro: Imprensa Nacional, 1910. Grifo nosso.

${ }^{37}$ ROCHA, Leandro Mendes. Da proteção fraternal ao integracionismo harmonioso: aspectos ideológicos da política indigenista - 1930/1967. Brasília: Fundação Nacional do Índio, 1993, p. 13. Grifo nosso.

${ }^{38}$ MENDES, Raimundo Teixeira apud LEITE, Jurandyr C. F. Proteção e incorporaçãa: a questão indígena no pensamento político do Positivismo ortodoxo, op. cit., p. 265.

${ }^{39}$ Idem.

${ }^{40}$ Ibidem, p. 265-266.

${ }^{41}$ Ibidem, p. 269.
} 
A "Proteção Oficial" significava "transformar os índios em pequenos produtores rurais capazes de se autossustentarem". ${ }^{42}$ Ainda tratando da passagem da categoria catequese para a nova orientaçáo seguida pelo governo federal no trato com os nativos, Lima destaca:

membros de ordens religiosas na qualidade de funcionários de uma administração estatizada para o trabalho direto com os povos indígenas). O substituto seria a presença militar e o uso do termo proteção. O uso instrumental do termo proteçáo era fato consciente e parte da luta pela laicização dos serviços estatizados e dos recursos materiais que envolviam. ${ }^{43}$

O autor enfatiza que a utilização do termo "proteção fraternal" não deve ser confundida com o uso da categoria "proteção", no sentido da reivindicação de atuação do Estado. ${ }^{44}$ Segundo Lima "proteção fraternal":

(...) era adotada por agentes e agências situadas nos campos político e intelectual com evidente predomínio de participantes diretos ou indiretos do aparelho de Estado. Cabe lembrar que o Apostolado Positivista do Brasil, atuando como propagandista através dos escritos de Teixeira Mendes, era uma agência que poder-se-ia — ao menos hipoteticamente — situar como integrante do campo politico para o caso. ${ }^{45}$

Além disso, o termo "proteção fraternal" deve ser entendido na intersecção entre os interesses de diversos grupos voltados para empreender as práticas estatais para com os nativos. Dentre esses grupos, podemos mencionar os militares, os intelectuais e os latifundiários:

Serviço que tem para campo de açáo toda a vastidão do território nacional, desdobrando-se em uma sequência de atos que náo podem ser interrompidos, sob a pena de malogro de todo o trabalho em andamento, de todo esforço dispendido, serviço que se dirige a um tempo à natureza selvagem do solo e à natureza selvagem de seu habitante, necessitando do emprego de métodos experimentais de cultura e da prática de processos científicos de civilização no desbravamento das terras e no trato da alma humana (...) só pode ser executado por crescido número de funcionários de várias categorias, num grande cerco de paz, num assédio extenso e paciente. ${ }^{46}$

Lima desmistifica o que vem a ser esse "grande cerco de paz":

${ }^{42}$ LIMA, Antônio Carlos de Souza. Um grande cerco de paz: poder tutelar e indianidade no Brasil, op. cit., p. 159.

${ }_{43}^{4}$ Ibidem, p. 115. Grifo nosso.

${ }^{44}$ LIMA, Antonio Carlos de Souza. Sobre indigenismo, autoritarismo e nacionalidade: consideraçóes sobre a constituição do discurso e da prática da Proteção Fraternal do Brasil, op. cit., p. 189-190.

${ }^{45}$ Ibidem, p. 190. Grifo nosso.

${ }^{46}$ RONDON, Cândido apud LIMA, Antônio Carlos de Souza. Um grande cerco de paz: poder tutelar e indianidade no Brasil, op. cit., p. 130. Grifo nosso. 
A imagem do grande cerco de paz revela-se em toda a sua complexidade nas palavras do militar, sumarizando numerosos mecanismos ainda hoje em ação: técnica militar de pressionamento e forma de manter a vigilância, ao mesmo tempo assédio de um inimigo visando cortar-lhe a liberdade de circulação (...). (...) além de defesa contra os de fora do cerco, como num cercado para as crianças, estabelecendo limites e constriçôes aos por ele incluídos/excluídos, numa amplitude que deveria justificar um numeroso quadro administrativo de fato hoje em dia existente. Modo tático de sublimação da guerra e forma de denegar a violência aberta, construída sobre os alicerces da ciência da época e não mais da religião, a imagem do cerco, estabelecido pelo terceiro elemento constituído idealmente pela administração (...) da divisão imposta, produzindo índios e civilizados. ${ }^{47}$

Mesmo que na ordem do dia estivesse a busca da identidade nacional, e junto desse plano fosse buscada a modernização do país, os nativos, mesmo reconhecidos como parte integrante da nação, continuavam a ter suas identidades culturais suprimidas por práticas ou políticas indigenistas ${ }^{48}$ que, de alguma forma, já eram executadas desde o período colonial. Um exemplo disso era a catequização do índio, praticada há séculos como uma forma de "amansar" os nativos, com o intuito de assimilá-los à cultura europeia.

Os primitivos habitantes do território brasileiro, os nativos, deveriam ser, portanto, integrados à sociedade nacional. As autoridades nacionais os enquadravam na categoria de seres inferiores, desrespeitados como etnias portadoras de cultura e caracterizados justamente por suas distintas formaçóes culturais. ${ }^{49}$

\section{Considerações finais}

A partir da filosofia comteana, foram analisadas, ao longo desse trabalho, as proposiçóes para a civilização dos nativos, lançada pelo Apostolado Positivista do Brasil, e para a instituição do SPILTN, que previam que os indígenas deveriam evoluir sem maiores interferências da civilização. Percebe-se que houve consonância entre as ideias defendidas pelos positivistas e a política indigenista instituída pelo governo federal. Porém, na prática, ocorreram adaptaçôes a partir dos interesses do próprio Estado Nacional. Ainda se pode afirmar que doutrinas advindas da Europa, como o Positivismo, sofreram interpretaçóes e, por consequência, ajustes foram propostos e empreendidos, particularmente no que tange à política estatal para as populações indígenas brasileiras.

\footnotetext{
${ }^{47}$ Ibidem, p. 131. Grifo nosso.

${ }^{48}$ Lima caracteriza a expressão política indigenista, que "designaria as medidas práticas formuladas por distintos poderes estatizados, direta ou indiretamente incidentes sobre os povos indígenas”. LIMA, Antônio Carlos de Souza. Um grande cerco de paz: poder tutelar e indianidade no Brasil, op. cit., p. 15)

${ }^{49}$ BARTH, Fredrik. Los grupos étnicos y sus fronteiras: la organización social de las diferencias culturales, op. cit.
} 


\section{Referências bibliográficas}

ALONSO, A. Ideias em movimento: a geração 1870 na crise do Brasil-Império. São Paulo: Paz e Terra, 2002.

BARTH, Fredrik. Los grupos étnicos y sus fronteiras: la organización social de las diferencias culturales. México: Fondo de Cultura Económica, 1976.

O guru, o iniciador e outras variaçóes antropológicas. Rio de Janeiro: Contra Capa, 2000.

CALDEIRA, Jorge. José Bonifácio de Andrada e Silva. São Paulo: Editora 34, 2002.

CARVALHO, José Murilo. A formação das almas: o imaginário da República do Brasil. São Paulo: Companhia das Letras, 1990.

- Construção da ordem: a elite política imperial e Teatro de Sombras: a política imperial. Rio de Janeiro: UFRJ, 1996.

COMTE, Auguste. Catecismo Positivista: ou sumária exposição da religião da humanidade. Tradução de Miguel Lemos. Rio de Janeiro: Igreja e Apostolado Positivista do Brasil, [1852] 1934. CUNHA, Manuela Carneiro da. Os direitos do indio: ensaios e documentos. São Paulo: Brasiliense, 1987.

GAGLIARDI, José Mauro. O indigena e a República. São Paulo: Hucitec, 1989.

HARTOG, François. O espelho de Heródoto: ensaio sobre a representação do outro. Belo Horizonte: Editora UFMG, 1999.

LINS, Ivan. História do Positivismo no Brasil. Sáo Paulo: Companhia Editora Nacional, 1964. LEITE, Jurandyr C. F. Proteção e incorporação: a questão indígena no pensamento político do Positivismo ortodoxo. Revista de Antropologia, v. 30/31/32, p. 255-275, 1989.

LEMOS, Miguel. José Bonifácio. A propósito do novo serviço de proteção aos indios. Rio de Janeiro: Igreja e Apostolado Pozitivista do Brasil, Tip. do IPB, n. 305, p. 1-5, set. 1910.

LIMA, Antonio Carlos de Souza. Sobre indigenismo, autoritarismo e nacionalidade: consideraçóes sobre a constituição do discurso e da prática da Proteção Fraternal do Brasil. In: OLIVEIRA FILHO, João Pacheco de (Org.). Sociedades indígenas e indigenismo no Brasil. Rio de Janeiro: Marco Zero, 1987.

. Um grande cerco de paz - poder tutelar e indianidade no Brasil. Tese (Doutorado em Antropologia Social) - Programa de Pós-graduação em Antropologia Social, Universidade Federal do Rio de Janeiro, Rio de Janeiro, 1992.

Um grande cerco de paz: poder tutelar e indianidade no Brasil. Rio de Janeiro: Vozes, 1995.

Reconsiderando poder tutelar e formação de Estado no Brasil: notas a partir da criação do Serviço de Proteção aos Índios e Localização de Trabalhadores Nacionais. In: FREIRE, Carlos Augusto da Rocha (Org.). Memória do SPI: textos, imagens e documentos sobre o Serviço de Proteção aos Índios (1910-1967). Rio de Janeiro: Museu do Índio/Funai, 2011, p. 201-211. 
MELO FRANCO, Afonso Arinos de. $O$ indio brasileiro e a Revoluçáo Francesa: as origens brasileiras da teoria da bondade natural. Rio de Janeiro: Topbooks, 1976.

MENDES, Raimundo Teixeira. A civilização dos indigenas brasileiros e a politica moderna. Rio de Janeiro: Igreja e Apostolado Positivista do Brasil, n. 294, jan. 1910.

. Em defesa dos selvagens brasileiros. Rio de Janeiro: Igreja e Apostolado Positivista do Brasil, Tip. do IPB, n. 300, maio 1910.

- A influência positivista no atual Serviço de Proteção aos Índios e Localização dos Trabalhadores Nacionais. Rio de Janeiro: Igreja e Apostolado Positivista do Brasil, Tip. do IPB, n. 334, jun. 1911.

MIRANDA, Rodolpho. Exposição de Motivos e Decreto n. 8.072 de 20 de junho de 1910. Rio de Janeiro: Imprensa Nacional, 1910.

OLIVEIRA FILHO, João Pacheco de. Ensaios em antropologia histórica. Rio de Janeiro: Editora UFRJ, 1999.

PEZAT, Paulo Ricardo. Auguste Comte e os fetichistas: estudo sobre as relaçóes entre a Igreja Positivista do Brasil, o Partido Republicano Rio-Grandense e a política indigenista na República Velha. Dissertação (Mestrado em História) — Programa de Pós-graduação em História, Universidade Federal do Rio Grande do Sul, Porto Alegre, 1997.

RIBEIRO, Darci. Os indios e a civilização: a integração das populaçóes indígenas no Brasil moderno. Petrópolis: Vozes, 1986.

ROCHA, Leandro Mendes. Da proteção fraternal ao integracionismo harmonioso: aspectos ideológicos da política indigenista — 1930/1967. Brasília: Fundação Nacional do Índio, 1993. SAHLINS, Marshall. O "pessimismo sentimental” e a experiência etnográfica: Por que a cultura não é um "objeto" em via de extinção (Parte I). Mana, Rio de Janeiro, v. 3, n. 1, p. 41-73, abr. 1997.

. História e cultura: apologias a Tucídides. Rio de Janeiro: Zahar, 2006.

SILVA, José Bonifácio Andrada e. Apontamentos para a civilização dos índios bravos do Império do Brasil. In: CALDEIA, Jorge. José Bonifácio de Andrada e Silva. São Paulo: Editora 34, 2002, p. 183-199.

SPONCHIADO, Breno Antônio. O Positivismo e a colonização do norte do Rio Grande do Sul. Frederico Westphalen: URI, 2005.

VIVEIROS, Esther de. Rondon conta sua vida. Rio de Janeiro: Livraria São José, 1958. 